\title{
Development of designs for table cloth through CAD software
}

Received: 28.05.2014; Revised: 22.03.2015; Accepted: 26.03.2015

See end of the paper for authors' affiliations VANDANA GUPTA

Department of Textiles and Apparel Designing, I.C. College of Home Science, C.C.S. Haryana Agricultural University, HISAR (HARYANA) INDIA

Email : vandana.g178@gmail.com
ABSTRACT : The present study was conducted to develop designs for table cloth through CAD software. Most preferred forty Greek motifs in eight different categories i.e. animal, human, pottery, foliage, stylized, architectural, geometrical and stylized flora fauna were used to develop twenty designs on AutoCAD software. Developed designs were shown to the respondents for their preferences in regard to different parameters i.e. innovation, placement of motifs and overall appearance and preferences regarding the 10 most preferred designs were taken.

KEY WORDS: CAD software, Greek motifs, Textile designing, Table cloth

- HOW TO CITE THIS PAPER : Gupta, Vandana and Joseph, Ruby (2015). Development of designs for table cloth through CAD software. Asian J. Home Sci., 10 (1) : 60-64. 